\title{
Improving the Quality of City Cleanliness through Investment Paradiplomacy in Bantaeng, Indonesia
}

\author{
Ahmad Harakan ${ }^{1 *}$, Nuryanti Mustari ${ }^{1}$, and Abel Alfred Kinyondo ${ }^{2}$ \\ ${ }^{1}$ Universitas Muhammadiyah Makassar, 90221, Makassar, Indonesia \\ ${ }^{2}$ University of Dar es Salaam, TZ-01, Dar Es Salaam, Tanzania
}

\begin{abstract}
The phenomenon of governance after the Reformation was the provision of more excellent opportunities for local governments to explore the capabilities and resources of their respective regions. Autonomy reflects the centralization policy that was previously implemented and is considered to have not been maximal in producing quality governance improvements, especially in cleanliness, which is the main problem in governance. This opportunity can be implemented by conducting learning and collaboration with other parties, both private and local governments abroad, who have a best practice profile of cleanliness governance through paradiplomacy practices. This research wants to obtain in-depth data. Data collection was carried out in three ways, namely interviews, observation, and documentation studies, through a qualitative approach with the case study method. The learning Process and cooperation in the Bantaeng Regency government impact changing people's views and making hygiene management policies in Bantaeng. Besides, there is technology transfer to support the effectiveness and efficiency of waste management and city cleanliness in Bantaeng Regency.
\end{abstract}

\section{Introduction}

City cleanliness is a sign of resource sustainability [1]. An area without spatial planning with a vision of sustainability with simple practices such as city cleanliness cannot make its environment and community resilient [2]. However, it needs to be emphasized that cleanliness is the biggest obstacle in various countries [3]. Government can solve this cleanliness problem if they can build a network and ensure that the community participates [4].

The current era of decentralization of authority provides opportunities for local governments to build networks and ensure public participation in environmental hygiene and sustainability agendas [5]. The given authority is facilitated by a series of academic conceptual, rules, and practices implemented even though with different focuses [6]. In the conceptual academic realm, various rules and practices implemented by sub-state actors

* Corresponding author: ahmad.harakan@unismuh.ac.id 
(local government) in building cooperation with other parties abroad are termed paradiplomacy [7].

Research on paradiplomacy in Indonesia rarely touches on environmental and sustainability studies. From the various available references, paradiplomacy studies are still dominated by practices related to local political movement [8], investment [9], disaster [10], and smart city [11], as seen in figure 1. Although limited, these practices indicate wider involvement of local governments to develop their respective areas.

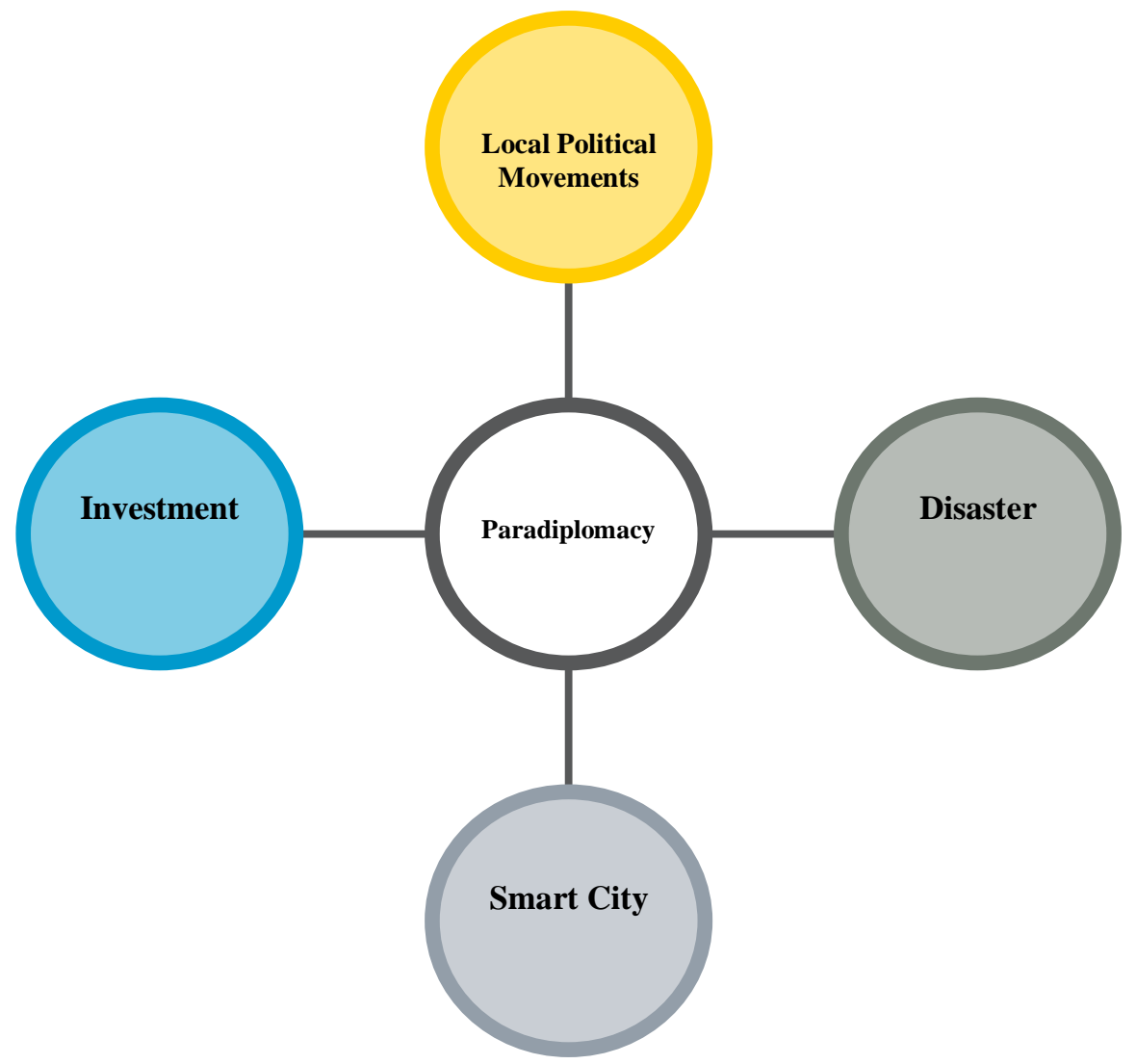

Fig. 1. Various issue of paradiplomacy in Indonesia.

One of the districts concerned with urban planning, especially on cleanliness and environmental sustainability, is Bantaeng Regency [5]. At least that attention was carried out by the Regent named Nurdin Abdullah, who led for two periods (2008-2018) [5]. The opportunity used is implemented by learning and collaborating with other parties, both private and local governments abroad, who have a profile of best practice hygiene governance and the best sustainable environmental vision through paradiplomacy practices.

This study offers a novelty by snapshot government actions in realizing city cleanliness and environmentally sound development and sustainable vision carried out by the Regional Government during Nurdin Abdullah's leadership in Bantaeng Regency through investment paradiplomacy schemes and practices. 


\section{Methods}

This research with the theme of paradiplomacy uses a qualitative type of research through a comprehensive tracking study. The technique of determining informants was carried out by purposive sampling through key persons, by choosing the group of participants who became informants according to the selected criteria relevant to the research problem. Observation, interview, and documentation are data and information collection techniques in this research. The interview technique used is an in-depth interview through a semi-structured approach to finding problems more openly and obtaining information from someone by asking questions based on the research objectives. Data analysis refers to the flow of activities that have been carried out, namely data collection, data reduction, display, and draw conclusions or verification.

\section{Result and Discussion}

Bantaeng Regency has mountainous, low-lying and coastal contours, as shown in figure 2. This factual condition provides its advantages for the government and the community who can respond to current opportunities.

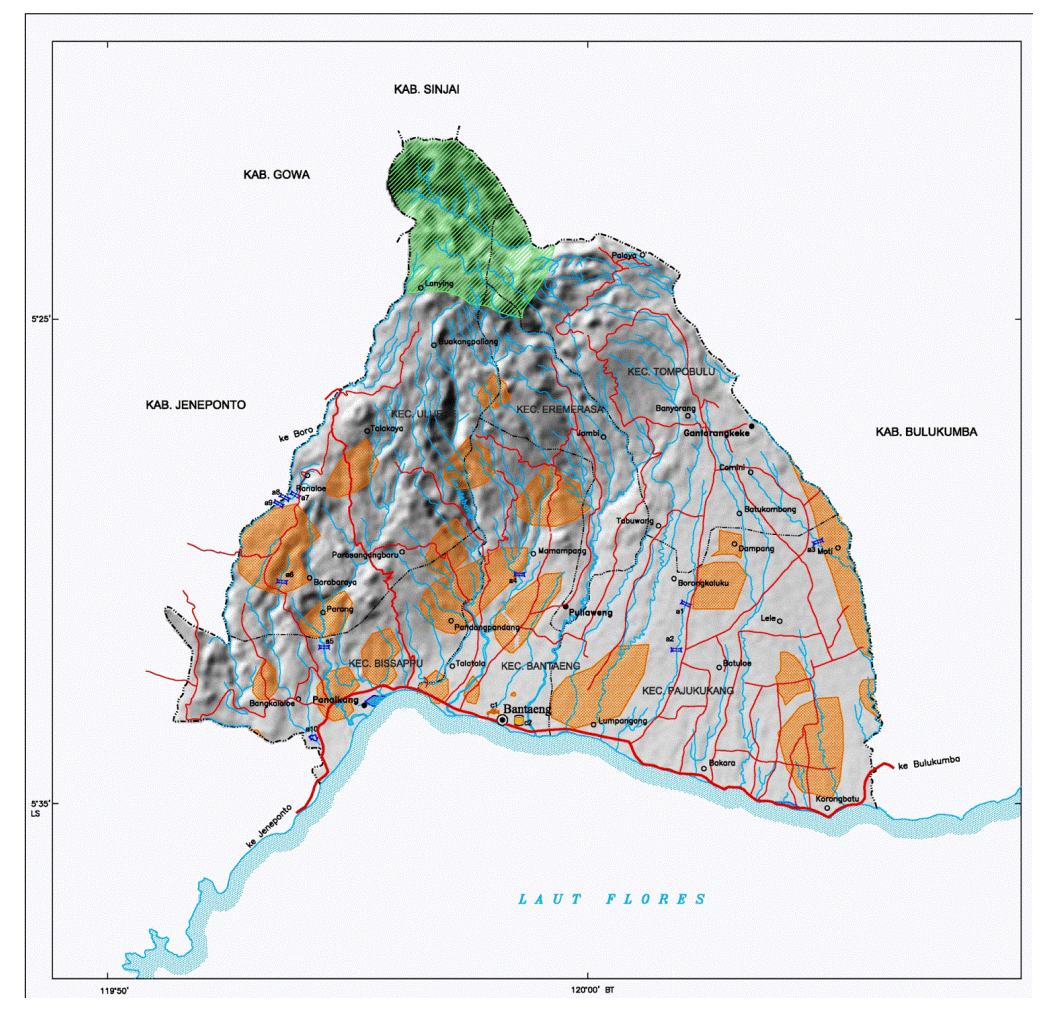

Fig. 2. Map of Bantaeng, Indonesia.

During Nurdin Abdullah's leadership as Regent in Bantaeng Regency, there were a series of collaborations carried out with the government and corporations abroad to support the success of the development with investment scheme $[12,13]$. Not just development for 
infrastructure, but another concern that the government mainstreams in the area are cleanliness and sustainability [5].

Paradiplomacy is considered a new alternative to improve the quality of the governance index in the regions [14]. The application of paradiplomacy in the service is also inseparable from the capability of local government leader to build extensive networks and convince other Paradiplomacy actors. The paradiplomacy practice is what Nurdin Abdullah did while he was the Regent of Bantaeng Regency [5,12].

In resolving urban cleanliness issues and establishing a sustainable, environmentally sound vision, active collaboration with other parties who have extensive experience is required [15]. The Regional Government in Bantaeng Regency during the Nurdin Abdullah Leadership Era established close collaboration with the government and corporations from Japan [16].

Collaboration between local governments and stakeholders from Japan is not only limited to investment of infrastructure development. Several things were adopted and applied to government and community activities to impact extraordinary changes in the way the community views the Bantaeng Regency.

Some of the things adopted include legal regulations related to environmentally sound development. Environmental-friendly laws will undoubtedly impact the formation of policies that do not injure the spirit of sustainability as stated in the Sustainable Development Goals [17]. In addition, there is an excellent transfer of technology and management in realizing urban cleanliness. The technology transfer is in the form of a garbage car with the latest technology, which local government will use garbage car for the first time in Eastern Indonesia. The existence of this technology transfer also changes the management of cleaning management. There are alternative models used in managing hygiene such as the Multi-Level Assessment Model [18].

This collaboration also impacts changing the perspective and philosophy of life of the people who start to acculturate local culture with the philosophy of kaizen. The Kaizen philosophy emphasizes the importance of productivity and continuous improvement of one's own life and the environment.

Various positive things obtained by the government and the community in Bantaeng Regency cannot be separated from the expertise of Nurdin Abdullah as the Regent in seeing opportunities, facilitating investment permits, and practicing paradiplomacy. With the selection of Bantaeng Regency as the beneficiary of Adipura for seven consecutive years, a series of collaborations through the transfer of technology and ideas, boosting the quality of human resources, was accomplished. Bantaeng Regency has also won a green city award, an environmental award, and 12 Adiwiyata schools in Bantaeng Regency and a profile of best practice in hygiene and environmental governance in Indonesia marked by a series of work visits and lessons learned from other local governments.

\section{Conclusion}

Although the concept of paradiplomacy has not been widely heard in the implementation of government, especially at the district level, however, in the spirit of significant change and led by a Regent who has a breakthrough and extensive network, the investment Paradiplomacy practice can be adequately implemented and has a positive impact on changes in hygiene management in Bantaeng Regency.

The network and cooperation built with the Japanese turned out to have a positive and tangible impact on supporting the vision of a sustainable environment. A series of collaborations through the transfer of technology and ideas, improving the quality of human resources was realized with the election of Bantaeng Regency as the recipient of Adipura for seven consecutive years. Bantaeng Regency has also won a green city award, an 
environmental award, and 12 Adiwiyata schools in Bantaeng Regency and a profile of best practice in hygiene and environmental governance in Indonesia marked by a series of work visits and lessons learned from other local governments.

All authors are grateful to the Lembaga Penelitian, Pengembangan dan Pengabdian Kepada Masyarakat, Universitas Muhammadiyah Makassar, Indonesia, for funding this study through an International Collaborative Research Grant with Contract Number: 004/KONTRPENL/PENGABD/IV/1442/2021. We would also like to thank the University of Dar es Salaam in Tanzania for their collaboration through the research and publishing process.

\section{References}

1. J. Macke, J. A. Rubim Sarate, and S. de Atayde Moschen, J. Clean. Prod. 239, 118103 (2019)

2. T. Jack, M. Anantharaman, and A. L. Browne, Soc. Cult. Geogr. 1 (2020)

3. A. S. Permana, S. Towolioe, N. A. Aziz, and C. S. Ho, Habitat Int. 49, 197 (2015)

4. D. Bednarska-Olejniczak, J. Olejniczak, and L. Svobodová, Sustainability 11, 332 (2019)

5. A. Harakan, M. Rahman, and N. Hartaman, Psychol. Educ. 58, (2021)

6. J. L. J. Hazenberg, Decentralization Gov. Indones. 31 (2015)

7. S. Wolff, Bol. Cent. J. Int. Aff. 10, (2007)

8. T. A. Mukti, T. Warsito, S. Surwandono, I. Badruzaman, and U. Pribadi, Eur. J. East Asian Stud. (2019)

9. A. Harakan, Paradiplomasi Investasi (Samudra Biru, Yogyakarta, 2020)

10. A. A. Resty, DAULIYAH J. Islam. Int. Aff. 3, (2018)

11. T. N. Mursitama and L. Lee, IOP Conf. Ser. Earth Environ. Sci. 126, 012102 (2018)

12. A. Harakan, J. Power Int. Relations 3, (2018)

13. M. Hatherell, Political Representation in Indonesia: The Emergence of the Innovative Technocrats (Routledge, Oxfordshire, 2019)

14. S. Surwandono and A. Maksum, Glob. J. Polit. Int. 22, 77 (2020)

15. Y. Truelove and K. O’Reilly, Environ. Plan. E Nat. Sp. 251484862094152 (2020)

16. M. Haboddin and L. Afala, in Proc. Proc. First Brawijaya Int. Conf. Soc. Polit. Sci. BSPACE, 26-28 November, 2019, Malang, East Java, Indones. (EAI, 2020)

17. S. Dailiati, I. Irawati, and P. Marlinda, IOP Conf. Ser. Earth Environ. Sci. 469, 012112 (2020)

18. W. Li, B. Bhushan, J. Gao, and P. Zhang, Int. J. Softw. Eng. Knowl. Eng. 28, 1755 (2018) 